\title{
Dissemination of antibiotic resistance genes associated with the sporobiota in sediments impacted by wastewater
} \author{
Bueche $^{1}{ }^{\text {, Gilbert Greub }}{ }^{4}$, Helmut Buergmann ${ }^{3}$, Pilar Junier ${ }^{\text {Corresp. } 1}$ \\ 1 Institute of Biology, Laboratory of Microbiology, University of Neuchatel, Neuchâtel, NE, Switzerland \\ 2 Vital-IT, Swiss Institute of Bioinformatics, Lausanne, Switzerland \\ 3 EAWAG, Swiss Federal Institute of Aquatic Science and Technology, Kastanienbaum, Switzerland \\ 4 Institute of Microbiology, University Hospital Center, University of Lausanne, Lausanne, Switzerland \\ Corresponding Author: Pilar Junier \\ Email address: pilar.junier@unine.ch
}

Christophe Paul $^{1}$, Zhanna Bayrychenko ${ }^{1}$, Thomas Junier ${ }^{2}$, Sevasti Filippidou ${ }^{1}$, Karin Beck ${ }^{3}$, Matthieu

Aquatic ecosystems serve as a dissemination pathway and a reservoir of both antibiotic resistant bacteria (ARB) and antibiotic resistance genes (ARG). In this study, we investigate the role of the bacterial sporobiota to act as a vector for ARG dispersal in aquatic ecosystems. The sporobiota was operationally defined as the resilient fraction of the bacterial community withstanding a harsh extraction treatment eliminating the easily lysed fraction of the total bacterial community. The sporobiota has been identified as a critical component of the human microbiome, and therefore potentially a key element in the dissemination of ARG in human-impacted environments. A region of Lake Geneva in which the accumulation of ARG in the sediments has been previously linked to the deposition of treated wastewater was selected to investigate the dissemination of tet(W) and sul1, two genes conferring resistance to tetracycline and sulfonamide, respectively. Analysis of the abundance of these ARG within the sporobiome (collection of genes of the sporobiota) and correlation with community composition and environmental parameters demonstrated that ARG can spread across the environment with the sporobiota being the dispersal vector. A highly abundant OTU affiliated with the genus Clostridium was identified as a potential specific vector for the dissemination of tet(W), due to a strong correlation with tet(W) frequency (ARG copy numbers/ng DNA). The high dispersal rate, long-term survival, and potential reactivation of the sporobiota constitute a serious concern in terms of dissemination and persistence of ARG in the environment. 
1 Dissemination of antibiotic resistance genes associated with the sporobiota in sediments

2 impacted by wastewater

3

4 Short title: ARG dissemination in the sporobiome

5

6

7

8 Christophe Paul $^{1 *}$, Zhanna Bayrychenko ${ }^{1 *}$, Thomas Junier ${ }^{2}$, Sevasti Filippidou1, Karin Beck ${ }^{3}$,

9 Matthieu Bueche ${ }^{1}$, Gilbert Greub ${ }^{4}$, Helmut Bürgmann ${ }^{3}$, Pilar Junier ${ }^{1 \&}$

${ }^{1}$ Laboratory of Microbiology, Institute of Biology, University of Neuchâtel, Rue Emile-Argand

11, CH-2000, Neuchâtel, Switzerland

${ }^{2}$ Vital-IT group, Swiss Institute of Bioinformatics, CH-1015, Lausanne, Switzerland

14 Eawag, Swiss Federal Institute of Aquatic Science and Technology, CH-6047, Kastanienbaum,

15 Switzerland

$16{ }^{4}$ Institute of Microbiology, University Hospital Center, University of Lausanne, CH-1011,

17 Lausanne, Switzerland.

18

$19{ }^{*}$ These authors contributed equally to this work.

\& corresponding author: pilar.junier@unine.ch

21

22 


\section{Abstract}

Aquatic ecosystems serve as a dissemination pathway and a reservoir of both antibiotic resistant bacteria $(\mathrm{ARB})$ and antibiotic resistance genes (ARG). In this study, we investigate the role of the bacterial sporobiota to act as a vector for ARG dispersal in aquatic ecosystems. The sporobiota was operationally defined as the resilient fraction of the bacterial community withstanding a harsh extraction treatment eliminating the easily lysed fraction of the total bacterial community. The sporobiota has been identified as a critical component of the human microbiome, and therefore potentially a key element in the dissemination of ARG in humanimpacted environments. A region of Lake Geneva in which the accumulation of ARG in the sediments has been previously linked to the deposition of treated wastewater was selected to investigate the dissemination of $\operatorname{tet}(\mathrm{W})$ and sul1, two genes conferring resistance to tetracycline and sulfonamide, respectively. Analysis of the abundance of these ARG within the sporobiome (collection of genes of the sporobiota) and correlation with community composition and environmental parameters demonstrated that ARG can spread across the environment with the sporobiota being the dispersal vector. A highly abundant OTU affiliated with the genus Clostridium was identified as a potential specific vector for the dissemination of tet $(\mathrm{W})$, due to a strong correlation with tet(W) frequency (ARG copy numbers/ng DNA). The high dispersal rate, long-term survival, and potential reactivation of the sporobiota constitute a serious concern in terms of dissemination and persistence of $A R G$ in the environment.

\section{Introduction}


47 The prevalence and spread of antibiotic resistance is a pressing global public health issue (Marti,

48 Variatza \& Balcazar, 2014; Perry, Westman \& Wright, 2014; O’Neill, 2015). Although

49 resistance to antibiotics was traditionally viewed as a clinical problem, attention has recently

50 been directed at understanding the ecological and environmental processes involved in the

51 dissemination of antibiotic-resistant bacteria (ARB) and their associated resistance genes (ARG)

52 (Berglund, 2015; Bengtsson-Palme, Kristiansson \& Larsson, 2017). The dispersal potential of

53 organisms (or genetic elements) carrying $\mathrm{ARG}$ is an important element to understand

54 dissemination of antibiotic resistance in the environment. In terms of dissemination, the so-called

55 "sporobiota" is a portion of the bacterial community of great interest. The sporobiota has been

56 defined as a fraction of the microbial community that can exist in the form of highly

57 transmissible spores, which are spread in the environment and are implicated in host-to-host

58 transmission (Tetz \& Tetz, 2017). This fraction of the community, which can be considered as

59 part of the seed bank (Lennon \& Jones, 2011; Shoemaker \& Lennon, 2018), is prone to high

60 dispersal rates due its non-active physiological state, bypassing limitations for local adaptation

61 (Bartholomew \& Paik, 1966; Hubert, 2009; Lennon \& Jones, 2011). The sporobiota appears to

62 play a significant role as part of the natural microbiota of humans (Browne et al., 2016), and

63 therefore, might be highly relevant for ARG dissemination in human-impacted environments.

64 Moreover, one of the features that has been ascribed to the sporobiome (collection of genes of

65 the sporobiota community) is its potential implication in the spread of antibiotic resistance (Tetz

66 \& Tetz, 2017; Bengtsson-Palme, Kristiansson \& Larsson, 2017). Although the initial definition

67 of the sporobiota in humans makes reference to a particular type of spores produced by the

68 phylum Firmicutes (heat-resistant endospores; Tetz and Tetz 2017), it is likely that other spore-

69 like structures are found as part of the environmental sporobiota. Therefore, in this study we use 
70 a more comprehensive operational definition based on the properties of the sporobiota. The

71 operational definition used here consists of cellular structures withstanding a harsh extraction

72 method designed originally to enrich in endospores from environmental samples (Wunderlin et

73 al., 2014).

Aquatic ecosystems can be considered as priority areas when investigating dispersal of ARG in

the environment. On the one hand, aquatic ecosystems have a reservoir function, allowing the mixing of environmental organisms and human/animal pathogens, potentially promoting gene transfer, mainly in sediments and biofilms (van Elsas \& Bailey, 2002; Kenzaka, Tani \& Nasu, 2010; Drudge, 2012). On the other hand, the use of water bodies for irrigation, recreational and domestic purposes, and as a drinking water supply (after treatment), constitutes a potential pathway enabling transmission of $\mathrm{ARB}$ (or $\mathrm{ARG)}$ between hosts through the environment (Baquero, Martínez \& Cantón, 2008; Taylor, Verner-Jeffreys \& Baker-Austin, 2011). In particular, water bodies connected to wastewater treatment plants (WWTPs) are a major concern (see Baquero, Martínez \& Cantón, 2008; Marti, Variatza \& Balcazar, 2014 for reviews in the topic). Many WWTPs not only collect wastewater from domestic sources, but also from hospitals or the food-industry, where antibiotics are extensively used (Szczepanowski et al., 2009; Bouki, Venieri \& Diamadopoulos, 2013; Rodriguez-Mozaz et al., 2015; Xu et al., 2015). Despite elaborate treatment and disinfection phases put in place in modern WWTPs, ARB and ARG have been shown to be only partially eliminated, thus potentially having an important impact on ARG transfer and dispersal (LaPara et al., 2011; Munir, Wong \& Xagoraraki, 2011; Dodd, 2012; Rizzo et al., 2013).

Lake Geneva is the largest freshwater lake in Western Europe and constitutes a major source of drinking water. The lake receives wastewater from the surrounding cities. The largest WWTP is 
93 located near the city of Lausanne and receives wastewater from both domestic and

94 industrial/clinical sources. Treated wastewater is released into a bay of the lake, the Vidy Bay.

95 An overflow associated with strong rain episodes also contributed to the occasional release of

96 untreated wastewater. Although a natural background of resistance genes is ubiquitous, and in

97 addition the entire Lake Geneva basin is likely affected by human activity, sediments of the Vidy

98 Bay are more significantly impacted in terms of organic and inorganic pollution by the WWTP

99 discharge, due to their immediate proximity to the outlet. Contamination by fecal-indicator

100 bacteria, trace metals, nitrogen, phosphorus, and ARG has been reported (Haller et al., 2011;

101 Czekalski et al., 2012; Thevenon et al., 2012; Czekalski, Gascón Díez \& Bürgmann, 2014;

102 Devarajan et al., 2015). Moreover, ARG and resistant bacteria have been detected close to the

103 drinking water pump of Lausanne, $3.2 \mathrm{~km}$ away from the WWTP outflow, highlighting the

104 potential risk for human health of the transfer of ARB and ARG from the environment back into

105 humans (Czekalski et al., 2012). Therefore, Lake Geneva constitutes an ideal system to evaluate

106 the role of the sporobiota in ARG dissemination. We have previously shown that the sporobiome

107 of lake sediment preserves a historical record of resistance prevalence using as proxies for ARG

108 the tet(W) and sul1 genes (Madueño et al., 2018) and the same genes were also selected for this

109 study. Although analyzing only two ARG limits the scope of our work and results should

110 therefore not be generalized, currently the low DNA yield resulting from the separation of the

111 sporobiota limits the number of genes that can be assessed simultaneously without total DNA

112 amplification. The $\operatorname{tet}(\mathrm{W})$ gene confers resistance to tetracycline, a class of natural antibiotics

113 isolated from Streptomyces that inhibit protein synthesis (Roberts, 1996). The sul1 gene confers

114 resistance to sulfonamide, a class of synthetic antibiotics that inhibit the enzyme dihydropteroate

115 synthase (DHPS) in the folic acid pathway (Sköld, 2001). Moreover, the sul1 gene has been 
116 suggested as a useful proxy for monitoring ARG in the environment (Berendonk et al., 2015).

117 Both genes are known to be abundant in wastewater-impacted sediments (Czekalski, Gascón

118 Díez \& Bürgmann, 2014; Na et al., 2014; Rodriguez-Mozaz et al., 2015), and in particular, the

119 high abundance of these two genes among total bacterial communities was previously reported in

120 sediments from the same location (Czekalski, Gascón Díez \& Bürgmann, 2014). Sulfonamides

121 and tetracyclines are still in use in human medicine and are the antibiotic classes with the highest

122 and third highest sales numbers, respectively, for the veterinary sector in Switzerland (Federal

123 Office of Public Health, 2016).

124 The aims of the present study were to investigate the accumulation of ARG tet(W) and sul1 in

125 DNA extracted from sediments treated to enrich the sporobiota and that are impacted

126 differentially by a WWTP discharge. In addition, we analyzed the sporobiota community

127 composition and its relationship to ARG levels, spatial distribution, and characteristics of 128 sediments.

\section{Material and methods}

131 Site description and sampling

132 Lake Geneva is the largest freshwater lake of Western Europe, with a volume of $89 \mathrm{~km}^{3}$, a 133 surface area of $580 \mathrm{~km}^{2}$ and a maximum depth of $309 \mathrm{~m}$. Vidy Bay is enclosed by the shoreline 134 near Lausanne between St.-Sulpice and Lausanne-Ouchy. The outlet pipe of the WWTP is 135 located $700 \mathrm{~m}$ offshore at $35 \mathrm{~m}$ depth $(46.51197121 \mathrm{~N} ; 6.587423025 \mathrm{E})$.

136 The ten cores used for this study were retrieved using standard corers $(50 \mathrm{~cm}$ length Plexiglas 137 tubes of $6 \mathrm{~cm}$ diameter) between July 2011 and May 2012 in three sampling zones differently 138 impacted by the WWTP (Bueche, 2014; Sauvain et al., 2014): 5-40 m from the outlet pipe of the 
139 WWTP ("near", N1-N4); 134-429 m from the outlet pipe ("middle”, M1-M4); and 611-956 m

140 from the outlet pipe ("distal", D1-D2). Two sediment layers were analyzed for the cores with the

141 code numbers 1 and 2 (D1, D2, M1, M2, N1, N2) [20]: 0-3 cm and 3-9 cm depth. Three

142 sediment layers were analyzed for the cores with the code numbers 3-4 (M3, M4, N3, N4): 0-1.5

$143 \mathrm{~cm}, 1.5-3 \mathrm{~cm}$ and 3-9 $\mathrm{cm}$ depth.

\section{DNA extraction}

146 Sporobiome DNA was obtained using an indirect three step extraction method: i) extraction of

147 cells from the sediment particles, ii) separation of spores from the vegetative cells, iii) DNA

148 extraction from the spores (Wunderlin et al., 2014).

149 The treatment to separate spores from vegetative cells was performed on the biomass from 1.5 150 grams of sediment collected on one nitrocellulose filter (Merck Millipore, Darmstadt, Germany)

151 per sample, as previously described (Wunderlin et al., 2014). The first step consisted of the lysis

152 of vegetative cells by heat, enzymatic agents (lysozyme) and chemicals (Tris-EDTA, NaOH, 153 SDS). The second step consisted of a DNase digestion in order to destroy the free DNA. Treated 154 filters were stored at $-20^{\circ} \mathrm{C}$ until DNA was extracted from the pre-treated filters using a modified 155 protocol with the FastDNA®SPIN kit for soil (MP Biomedicals, USA) (Wunderlin et al., 2013) 156 with the following additional modifications: lysing matrix were submitted to two successive 157 bead-beating steps. Supernatant retrieved from each bead-beating was treated separately 158 according to manufacturer's instructions and DNA extracts were pooled together at the end of 159 the procedure. Pooled DNA was precipitated with $0.3 \mathrm{M} \mathrm{Na}$-acetate and ethanol (99\%), stored at $160-20^{\circ} \mathrm{C}$ overnight and centrifuged for $1 \mathrm{~h}$ at $21460 \mathrm{xg}$ and $4^{\circ} \mathrm{C}$. Supernatant was removed and the 161 pellet was washed with $1 \mathrm{ml}$ of $70 \%$ ethanol and centrifuged for $30 \mathrm{~min}$ at $21460 \mathrm{xg}$ and $4{ }^{\circ} \mathrm{C}$. 
162 Supernatant was removed and the residual ethanol was allowed to evaporate at room 163 temperature. Pellet was re-suspended in $50 \mu 1$ of PCR-grade water. Total DNA was quantified

164 using Qubit ${ }^{\circledR}$ dsDNA HS Assay Kit on a Qubit ${ }^{\circledR}$ 2.0 Fluorometer (Invitrogen, Carlsbad, CA, 165 USA).

166

167 Real-time quantitative PCR on tet(W) and sull genes

168 Real-time Taqman ${ }^{\circledR}-\mathrm{PCR}$ on $\operatorname{sul1}$ and $\operatorname{tet}(\mathrm{W})$ genes was performed in 384-well plates using a 169 LightCycler ${ }^{\circledR} 480$ Instrument II (Roche, Switzerland). For sul1, the primers used were qSUL653f 170 (5'-CCGTTGGCCTTCCTGTAAAG-3') and qSUL719r (5'-TTGCCGATCGCGTGAAGT-3') 171 with tpSUL1 (FAM-CAGCGAGCCTTGCGGCGG-TAMRA) probe (Heuer \& Smalla, 2007). The 172 reaction mix for sull consisted of $2 \mu \mathrm{L}$ of DNA template (between 0.08 and $1.39 \mathrm{ng} / \mu \mathrm{L}$ ), 0.025 $173 \mu \mathrm{M}$ of each primer, $0.25 \mu \mathrm{M}$ of TaqMan probe and $1 \mathrm{x}$ TaqMan ${ }^{\circledR}$ Fast Universal PCR Master 174 Mix (Applied Biosystems, USA). Total reaction volume of $10 \mu \mathrm{L}$ was reached with PCR-grade 175 water. For tet(W), the primers used were tetWf (5'CGGCAGCGCAAAGAGAAC-3') and 176 tetW_r (5-CGGGTCAGTATCCGCAAGTT-3') with tetW_s (FAM-CTGGACGCTCTTACG-

177 TAMRA) probe (Walsh et al., 2011). The reaction mix for tet(W) consisted of $2 \mu \mathrm{L}$ of DNA 178 template, $0.025 \mu \mathrm{M}$ of each primer, $0.1 \mu \mathrm{M}$ of TaqMan probe and $1 \mathrm{x}$ TaqMan®Fast Universal 179 PCR Master Mix (Applied Biosystems, USA). Total reaction volume of $10 \mu \mathrm{L}$ was reached with 180 PCR-grade water. The qPCR program was the same for both genes and started with a hold at $18195^{\circ} \mathrm{C}$ for $10 \mathrm{~min}$, followed by 45 cycles of denaturation at $95^{\circ} \mathrm{C}$ for $15 \mathrm{~s}$ and 182 annealing/elongation at $60^{\circ} \mathrm{C}$ for $1 \mathrm{~min}$. The qPCR assays were performed in technical triplicates on samples, standards and negative controls. The negative controls consisted of PCR blanks with only the reaction mix and of PCR blanks containing the mix and $2 \mu \mathrm{L}$ of PCR-grade water. 
185 Standard curves were prepared from serial 10-fold dilutions of plasmid DNA containing the 186 respective target gene in a range of $5 \times 10^{7}$ to 50 gene copies. For $s u l 1$, control plasmids and 187 standard curves were prepared as previously described (Heuer \& Smalla, 2007). For tet(W), 188 standard curves were prepared as previously described (Walsh et al., 2011). The effect of 189 inhibitors on amplification was tested for all the samples and for both genes. All samples were 190 spiked with $10^{4}$ copies of plasmid DNA containing the tet(W) or the sull gene and amplified 191 together with the same set of non-spiked samples and control DNA and the results indicated that 192 inhibition was negligible.

193

194

195

196

197

198

199

200

201

202

203

204

205

206

207

\section{Sequencing and data analysis}

Purified DNA extracts were sent to Fasteris (Geneva, Switzerland) for 16S rRNA gene amplicons sequencing using Illumina MiSeq platform (Illumina, San Diego, USA), generating 250 bp paired-end reads. The hypervariable V3-V4 region was targeted using universal primers

Bakt_341F (5'-CCTACGGGNGGCWGCAG-3')

and

Bakt_805R

$\left(5^{\prime}-\right.$ GACTACHVGGGTATCTAATCC-3') (Herlemann et al., 2011). Analysis of the dataset was performed using Mothur (Schloss et al., 2009) following the MiSeq SOP (Kozich et al., 2013). The SILVA NR v123 reference database (Quast et al., 2013) was used for the alignment of amplicons and the taxonomic assignment of representative OTUs. After quality filtering and removal of chimeras, a total of 1818238 amplicons were obtained (408758 unique sequences). Singletons were removed prior to the clustering into OTUs and corresponded to 373374 sequences. Average neighbor clustering of the 1444864 remaining sequences (35384 unique sequences) with an identity threshold of $97 \%$ led to the identification of 6390 OTUs. Sequencing data was deposited to NCBI under the Bioproject accession number PRJNA396277. 
209 Statistical and multivariate analysis

210 Community and statistical analyses were performed using R version 3.4.0 (R Core Team, 2014)

211 and the phyloseq and vegan packages (McMurdie \& Holmes, 2013; Oksanen et al., 2017). The

212 distance of samples to the WWTP outflow is a combination (euclidian distance) of the distance

213 between the sample and the pipe on the east axis, the north axis (based on $\mathrm{CH}$ coordinates) and

214 the water column depth. It is expressed in meters. The difference in ARG levels between the 215 zones (near, middle and distal) was tested using analysis of variance (ANOVA) and Tukey's test 216 for pairwise comparisons. Pairwise correlations between environmental parameters (organic 217 carbon, total nitrogen, and concentration of cadmium, copper, iron, manganese, aluminum, zinc 218 and arsenic) and ARG abundance/frequency were calculated using Spearman's rank correlation 219 coefficient. This correlation coefficient was selected because we did not assume a normal 220 distribution of the variables. The organic carbon, total nitrogen, and metal concentrations were 221 obtained from previous studies (Bueche, 2014; Sauvain et al., 2014). P-values were adjusted for 222 family-wise error rate using the Holm method. Spearman's rank correlation coefficient was used 223 for calculating the correlations between ARG frequency and the relative abundance of OTUs. To 224 provide a visual representation of the distribution of the correlation coefficient of OTUs with 225 ARG concentration Kernel density curves were computed from Spearman's correlation 226 coefficients calculated between each ARG and OTU and can be thought of as continuous 227 histograms representing the frequency (density) of the correlation coefficients. The significance 228 of the Spearman's correlation coefficients was tested by correcting the $p$-values using the false 229 discovery rate correction (Benjamini-Hochberg method). This method was selected because of 230 the large number of comparisons performed. Principal component analysis (PCA) was computed 
231 on the environmental parameters and ARG abundance/frequency, after standardization (zero

232 mean and unit variance). The environmental parameters included were $\mathrm{C}_{\text {org }}, \mathrm{N}_{\text {tot }}$, metals (listed

233 above), distance to the outlet pipe (Dist_pipe), DNA abundance in ng per gram of sediment

234 (DNA_ng_gSed), and ARG abundance and frequency. Sporobiota community was analyzed by

235 principal coordinates analysis (PCoA), based on Bray-Curtis dissimilarity and Hellinger

236 transformation of the OTU table. Environmental parameters and ARG abundance/frequency

237 were standardized and passively fitted to the ordination. Only significant parameters were 238 displayed $(\mathrm{p}<0.05)$.

\section{Results}

\section{Prevalence and spatial distribution of $\operatorname{tet}(\mathrm{W})$ and sul1 in sporobiome DNA}

243 To determine the prevalence of the two selected ARG in DNA extracted from the sporobiota and

244 to describe their spatial distribution in sediments impacted by a WWTP, ARG quantification was

245 carried out for three zones located at 5-40 m (near) 134-429 m (middle) and 611-956 m (distal)

246 from the outlet pipe (Figure 1). These zones were previously shown to be differentially impacted

247 by the release of wastewater, according to the concentration of particulate trace and heavy metals

248 in the sediments and to the bacterial community composition (Sauvain et al., 2014). The results

249 of ARG quantification were expressed in two different units. The first unit, ARG abundance,

250 refers to the number of copies of ARG per $\mathrm{g}$ of sediment. This reflects accumulation in sediment

251 and represents the total ARG pool for a given ARG. However, differential microbial load in

252 sediments could bias this measure. Therefore, we used a second unit, ARG frequency, which is

253 defined as the number of copies of ARG per ng of extracted DNA. This allowed us to estimate 
254 the enrichment of specific ARG in DNA from the enriched sporobiota. We caution that both

255 approaches are potentially affected by changes in the proportion of different bacterial groups that

256 may not be causally related to either inputs or growth of ARB or local selection of ARG. For

257 example, an increase in abundance of a population without an ARG due to nutrient inputs will

258 result in a reduction of ARG frequency.

259 Both $\mathrm{ARG}$, tet(W) and sul1, were detected in DNA at all sampling locations. In all samples,

260 abundance and frequency were higher for tet $(\mathrm{W})$ than for sul1 (Table 1). The influence of the

261 WWTP as the main source of sporobiota-associated ARG can be observed in the spatial

262 distribution of ARG abundance. Abundance was highest in samples from the proximal zone and

263 decreased with distance to the outlet pipe (Figure 2, Supplementary Figures 1 and 2). This

264 pattern was confirmed by principal component analysis (PCA; Supplementary Figure 1) and

265 Spearman correlation tests (Supplementary Figure 3), which showed that ARG abundance was

266 mostly correlated with environmental variables associated to deposition of treated wastewater,

267 such as organic carbon content $\left(\mathrm{C}_{\text {org }}\right)$ and total nitrogen $\left(\mathrm{N}_{\text {tot }}\right)$ in sediments. However,

268 unexpectedly, the $\mathrm{R}^{2}$ calculated for the linear regression established between ARG abundance

269 and distance to the outlet pipe in our case (Supplementary Figure 2) was generally low.

270 Measures of ARG frequency showed that tet(W) and sull genes had different enrichment

271 patterns in the sporobiota. In the case of sull, ARG frequency decreases in relation to the

272 distance to the outlet pipe (Figure 2, Supplementary Figure 2). A decrease in frequency could be

273 attributed to dilution of a population with high sul1 frequency (originating from the wastewater)

274 within the environmental sporobiota community. The frequency of tet(W) also decreased in

275 relation to the distance to the outlet pipe, but its pattern of distribution was more complex. The

276 highest $\operatorname{tet}(\mathrm{W})$ frequencies were found in two middle zone samples (M1_low and M2_low, 
277 Figure 2, Supplementary Figure 1A). Both correlation tests (Supplementary Figure 3) and PCA

278 with the environmental variables (Supplementary Figure 1B) indicated a significant correlation

279 between $\operatorname{tet}(\mathrm{W})$ frequency and certain metals $(\mathrm{Fe}, \mathrm{As}$, and $\mathrm{Cu})$.

\section{Sporobiota community composition}

282 Several studies have demonstrated a strong impact of WWTP discharge on bacterial community composition, which is shown by changes in the community in impacted sediments compared to remote sites (LaPara et al., 2011; Czekalski, Gascón Díez \& Bürgmann, 2014; Sauvain et al., 2014). In previous studies using a different sequencing technology (pyrosequencing), the total bacterial communities analyzed from the same sediments were highly divergent, forming at least four distinct groups depending on the distance to the outlet pipe and the concentration of heavy and trace metals in the sediments (Bueche, 2014; Sauvain et al., 2014). In contrast, the sporobiota community has a low degree of variability among impacted and supposedly less impacted sites (Figure 3), suggesting that the distance to the wastewater outlet pipe had a relatively small impact on sporobiota community composition. Firmicutes are the dominant phylum in all samples (Supplementary Figure 4), accounting for at least $85.2 \%$ of the sporobiota community, except in sample taken from the middle area at a depth of 1.5-3 cm (M4_med; $65.9 \%$ ). This is in agreement with a previous study demonstrating an enrichment of $83.9-90.6 \%$ in Firmicutes using the same method for the isolation of spores (Wunderlin et al., 2014). Among the non-Firmicutes representatives, we found several groups for which the production of spores

297 is so far not reported and that could represent potential contamination with vegetative cells that withstood the extraction procedure (see below). Nevertheless, we performed the analysis with the 
299 entire community as our definition of the sporobiota considers the resilience to the extraction

300 method, rather than phylogenetic affiliation.

301 In terms of relative abundance, $43.1 \%$ of the whole community was identical between all 302 samples. The two most abundant genera, Clostridium_sensu_stricto_1 and an unclassified 303 Peptococcaceae, were the same for all samples (except M4 med), with an average relative 304 abundance of 57.3\%. Both are widely represented in the human gut (Lozupone et al., 2012), 305 which is also the case for other subdominant genera, including Intestinibacter (9.7\%), 306 Turicibacter (6.7\%), and Ruminococcus_2 (0.9\%). These findings suggest a common origin of 307 the sporobiome and point again at the WWTP as the main source of the sporobiome community 308 depositing in the lake sediment in the area studied here.

309 Despite the high homogeneity of the sporobiota community, principal coordinate analysis 310 (PCoA, Figure 4) reveals a slight variability among the communities. For example, in Axis 1, 311 Bacilli is associated with samples located at a greater distance from the outlet pipe, while 312 different Clostridia are associated to samples closer to the WWTP. While Clostridia are mostly 313 anaerobic and are common in the microbiome of humans and other mammals, Bacilli include 314 numerous aerobic organisms and are commonly found in soils (Madigan et al., 2015). 315 Accordingly, Clostridia could be seen as a signature of the human influence in the sporobiota 316 associated with wastewater discharge whereas Bacilli would represent a more environmental 317 sporobiota community.

318 In addition, PCoA revealed two groups of samples of particular interest (Figure 4). Group 1

319 (Gr.1 in Figure 4; Supplementary Figure 5B), which was characterized by high load of $\mathrm{C}_{\text {org }}$ and $320 \mathrm{~N}_{\text {tot }}$, and high abundance/frequency of $\mathrm{ARG}$, was composed of samples from the zone in close 321 proximity to the WWTP discharge. Among the OTUs associated to this group, the most abundant 
322 belong to the genera Bifidobacteria and Collinsella, two Actinobacteria common in the human 323 microbiome (Lamendella et al., 2008; Thorasin, Hoyles \& McCartney, 2015), albeit unknown for

324 the production of spores. Another abundant genus in this group is Trichococcus, a Firmicute

325 found in sewerage infrastructure and WWTP (Vandewalle et al., 2012). This group reflects the

326 direct influence of the WWTP (Supplementary Figure 5B). In contrast, Group 2 (Gr.2 in Figure

327 4; Supplementary Figure 5C) clustered samples from both the near and middle zones and was 328 related to elevated concentrations of particulate metals $(\mathrm{Zn}, \mathrm{Cd}, \mathrm{Cu}, \mathrm{As}$, and $\mathrm{Fe}$ ) and a high

329 frequency of tet(W) (Figure 4). OTUs defining this group belonged mainly to non-Firmicutes

330 (Supplementary Figure 5C). Some were affiliated to organisms that have been previously

331 isolated from WWTPs, including Synergistetes (Wang et al., 2013), Syntrophorhabdus (Saia et

332 al., 2016), Anaerolinaceae and Leptolinae (Yamada et al., 2006). Others were affiliated to 333 uncommon taxa previously isolated from rivers or aquifers, such as Gaiellales (Albuquerque et 334 al., 2011) and Kaistia (Jin et al., 2011). To our knowledge, there is no evidence that these 335 organisms are resistant to high metal contamination.

\section{Correlation tests between OTUs and ARG}

338 To further investigate the relationship between the sporobiota community and ARG distribution,

339 pairwise spearman correlation tests were performed between tet $(\mathrm{W})$ frequency and the relative 340 abundance of each OTU. For both tet(W) and sul1, the results indicated that only a small number 341 of OTUs correlate with the ARG studied here (Figure 5A-B). Interestingly, the 10 most 342 positively correlated OTUs were specific to each ARG. Although environmental correlations 343 alone are not sufficient to identify carriers of antibiotic resistance, the results can help to 344 highlight potential groups that merit further investigation. For example, the three most tet(W)- 
345 positively correlated OTUs (correlation coefficients ranging from 0.84 to 0.71 ) all belonged to

346 Firmicutes (Table 2). In particular, one of these OTUs (OTU00002;

347 Clostridium_sensu_stricto_1) was highly abundant (over 20\% of the relative abundance) in all

348 samples (Figure 5C). The known bacterial species most closely related to this OTU were

349 Clostridium celatum, Clostridium saudiense, and Clostridium disporicum, all isolated from the

350 feces of mammals, including humans, swine and rats (Horn, 1987; Angelakis et al., 2014;

351 Agergaard et al., 2016). Although in most Clostridium spp. studied so far, tetracycline resistance

352 is conferred by the $\operatorname{tet}(\mathrm{M})$ gene (Adams et al., 2002), $\operatorname{tet}(\mathrm{W})$ has been $\operatorname{detected}$ in a medical

353 isolate from Clostridium difficile (Spigaglia, Barbanti \& Mastrantonio, 2008). A similarity search

354 using this gene as a query showed the detection of homologues in various uncultured

355 environmental Clostridium spp. (Supplementary information). The other two most correlated

356 OTUs (Otu00045 and Otu00062) both belonged to the genus Ruminococcus_1, closely related to

357 Ruminococcus callidus and unclassified Ruminococcus spp., respectively. All of these have been

358 reported in human and other mammal feces (Wang, Cao \& Cerniglia, 1997; Leser et al., 2002;

359 Schmidt et al., 2011). Another OTU of interest was OTU00008, which represented up to 1.75\%

360 of the total community $(0.87 \%$ in average). OTU00008 was closely related to Ruminococcus

361 bromii, one of the predominant species in human, swine, and cattle gut (Moore, Cato \&

362 Holdeman, 1972; Klieve et al., 2007). Although the genus Ruminococcus was originally

363 considered as to comprise non-spore forming species, a recent report has demonstrated the

364 production of spores by Ruminococcus isolated from human colon and rumen (Mukhopadhya et

365 al., 2018). This gives additional support to our approach and shows the importance of defining

366 the sporobiota based on its properties, rather than on the reports of spore production in cultured 367 isolates. 
368 In spite of the widespread phylogenetic distribution of sul1 (Aminov, 2010), the 10 most sul1-

369 positively correlated OTUs belonged mainly to Actinobacteria (Table 2). The other most

370 correlated OTUs belonged to Firmicutes, Proteobacteria, and Saccharibacteria (all with a

371 correlation coefficient above 0.8 ). Unsurprisingly, all these highly correlated OTUs were closely

372 related to organisms commonly reported as part of the human/mammal microbiome and/or are

373 commonly found in WWTPs. Compared to tet(W), none of the best correlated OTUs represented

374 a major fraction of the sporobiome community $(<0.25 \%$ in average, Figure $5 \mathrm{D})$. However, one

375 has to be careful in the interpretation of these correlations. The system under study is mainly

376 driven by the influence of the WWTP. Most sul1-correlated OTUs were related to Group 1 and

377 their abundance correlates with high concentrations of $\mathrm{C}_{\text {org }}$ and $\mathrm{N}_{\text {tot }}$ and other environmental

378 indicators of the direct influence of treated wastewater release (Supplementary Figure 5).

\section{Discussion}

Our results show that the effluents from the studied WWTP have a clear impact on the deposition of ARG associated with the bacterial sporobiome in sediments. Higher concentrations of ARG were found in the proximity of the outlet pipe compared to a more distal zone. These results were expected given the reported effect of treated wastewater on the levels of ARG in WWTPimpacted environments. In a study evaluating the dissemination of ARG from a river receiving WWTP discharge and farming runoffs, a decrease of ARG abundance with distance to the source was measured, reflecting a decreasing anthropogenic impact. However, most ARG were detectable even in distant sediments (Chen et al., 2013). Another study investigating the spatial 
391 to 200 fold higher in the vicinity of the outlet pipe with exponential decline (ARG abundance

392 and concentration) as function to the distance to the WWTP outlet pipe (Czekalski, Gascón Díez

$393 \&$ Bürgmann, 2014).

394 The ARG investigated in the present study appeared to be differently enriched within the 395 sporobiota, which was reflected by their unequal distribution in the sediments. Our results also 396 suggest that the abundance of tet(W) in the sporobiota community is greater amounts than sul1. 397 This contrasts with previous studies quantifying ARG abundance within the total bacterial DNA, 398 which have shown that the abundance of $s u l 1$ was higher (or at least as abundant) than for other 399 ARG, including tet(W) (Munir, Wong \& Xagoraraki, 2011; Czekalski, Gascón Díez \& 400 Bürgmann, 2014; Guo et al., 2014; Rodriguez-Mozaz et al., 2015). In order to generalize this 401 interpretation, the analysis of additional ARGs within the sporobiota needs to be considered in 402 the future. This is even more relevant when taking into account the fact that the patterns of 403 dissemination of ARG associated with the sporobiota appears to be unique, as suggested by the 404 abundance of $\operatorname{tet}(\mathrm{W})$ across the area investigated. For instance, the low $\mathrm{R}^{2}$ calculated for the 405 linear regression between ARG abundance and distance (Supplementary Figure 2) demonstrated 406 that ARG spatial distribution associated to the sporobiome is not only a function of distance to 407 the outlet pipe (highest frequency of $\operatorname{tet}(\mathrm{W})$ found in the middle area). In contrast, a previous 408 study on total microbial community DNA reported the highest relative abundance (copy number 409 normalized by $16 \mathrm{~S}$ rRNA gene copy numbers) of tet(W) in the vicinity of the wastewater 410 discharge and a significant logarithmic decay in relative abundance with distance (Czekalski, 411 Gascón Díez \& Bürgmann, 2014). This suggests that tet(W) accumulation is specific to the 412 sporobiota community. Interestingly, highest tet $(\mathrm{W})$ frequencies were found among samples that 413 coincided with a high level of particulate metal concentration in sediments (Supplementary 
414 Figure 1B; Supplementary Figure 3). Correlation between ARG and metal concentration has

415 been observed in various environments (Berg et al., 2010; Knapp et al., 2011; Ji et al., 2012),

416 including a previous study in Vidy Bay (Devarajan et al., 2015). However, it should be noted that

417 not all the samples with high metal concentration have a high frequency of tet(W), suggesting

418 that there might be other reasons for the correlation observed rather than co-selection. Moreover,

419 co-selection is not expected for the sporobiota if the former is found in a metabolically inactive

420 state (spore), but only in the case of the vegetative growing state.

421 Persistence and dissemination of ARG within the sporobiota appeared to be correlated to a small

422 number of species. The abundance of these ARG-bearing microorganisms in the human/animal

423 microbiome and subsequent selection processes will strongly influence the potential of ARG to

424 accumulate and spread in the environment. Our results show that endospore-forming Firmicutes

425 play an important role in the environmental dissemination of certain ARG and thus, their

426 potentially long-term persistence in the environment. Firmicutes are expected to be a major

427 component of the sporobiota because of their ability to form endospores (Schleifer, 2009). In

428 addition, Firmicutes might constitute a proxy for anthropogenic impact as they are common in

429 the human microbiome (Browne et al., 2016). Moreover, this phylum includes a wide variety of

430 pathogens, especially within Clostridia (Popoff \& Bouvet, 2009).

431 Our results pointed to a Clostridium species as a potentially important vector for tet(W) 432 dissemination and accumulation. This provides experimental support for the implication of the 433 sporobiota and the sporobiome in the spread of antibiotic resistance (Tetz \& Tetz, 2017; 434 Bengtsson-Palme, Kristiansson \& Larsson, 2017). The results are in accordance with a previous 435 study investigating the natural reservoirs of antibiotic resistance in the human gut, which 436 revealed that tet $(\mathrm{W})$ was preferentially present within Clostridiaceae, Ruminococcaceae, and 
437 Lachnospiraceae (de Vries et al., 2011; van Schaik, 2015). Interestingly, the sample with the

438 lowest relative abundance of Firmicutes was also the one with the lowest abundance/frequency 439 of tet(W), suggesting that the abundance of Firmicutes in the sporobiome was a good predictor of $440 \operatorname{tet}(\mathrm{W})$ contamination.

441 Compared to tet $(\mathrm{W})$, a larger fraction of the community was correlated to sul1. Notably among 442 those were OTUs affiliated to Actinobacteria (Table 2). A recent study reported an increase in 443 Actinobacteria abundance that correlated to an increase in sull frequency in activated sludge 444 under tetracycline and sulfamethoxazole selection pressure, suggesting sul1 is well represented 445 in Actinobacteria (Zhang et al., 2016). In addition to Actinobacteria, OTUs belonging to 446 Firmicutes, Proteobacteria, and Saccharibacteria were also among the most correlated to sul1 447 frequency. This can be seen as a confirmation of the distribution of sull among a broad 448 taxonomic range of bacterial clades, which is reflected in the sporobiome. The association of 449 sulfonamide resistance with Class 1 Integrons and its transfer through horizontal gene transfer 450 might explain this broad taxonomic distribution (Aminov, 2010).

451 The selection of ARG may already occur within human microbiota. It is now largely accepted 452 that human intestinal bacteria not only exchange resistance genes among themselves, but can 453 also interact with other bacteria in the colon (Salyers, Gupta \& Wang, 2004). This makes the 454 human gut a potential reservoir of antibiotic resistance genes for pathogenic bacteria (Sommer, 455 Dantas \& Church, 2009). Resistant spore-formers are then partially released with human feces 456 and arrive in WWTPs, where (if in a vegetative state) they have the opportunity to mix and 457 engage in horizontal gene transfer with other bacteria. If the final treatment is not sufficient to 458 eliminate these organisms, they end up in the environment where they can interact with 459 environmental organisms (Baquero, Martínez \& Cantón, 2008). 


\section{Conclusion}

462

463 The presence of ARG in the sporobiome highlights that it may be difficult to remove the legacy 464 of resistance genes once released into the environment. Detecting ARG within this intrinsically 465 long-lasting fraction of the microbial community has also important implications for the 466 monitoring of ARG and the understanding of the processes explaining host-to-environment-to467 host spread of antibiotic resistance. Notably, several studies have reported the transport and 468 survival of thermophilic Firmicutes endospores in cold marine sediments, demonstrating their

469 high dispersal and survival propensity (Hubert, 2009; de Rezende et al., 2013). Likewise, 470 comparison with our previous study on a sediment core taken in the same basin but not directly 471 influenced by the wastewater treatment discharge (Rhone catchment area; Madueño et al., 2018) 472 showed also the enrichment of the sporobiota in the same resistance genes, providing further 473 evidence that the sporobiota is a significant vector for ARG transport over considerable distance 474 (Rhone river catchment). Moreover, the temporal analysis performed in our previous work 475 suggests that the sporobiota preserves the signature of ARG over long time scales (decades) 476 (Madueño et al., 2018). Even if environmental conditions become harsh, this highly resilient 477 fraction of the bacterial community can survive for long periods of time and may eventually re478 enter humans via drinking water or other routes of contact, which may constitute an important 479 long-term risk for human health.

\section{References}

482 Adams V., Lyras D., Farrow KA., Rood JI. 2002. The clostridial mobilisable transposons. 
484

485

486

487

488

489

490

491

492

493

494

495

496

497

498

499

500

501

502

503

504

505

Agergaard CN., Hoegh SV., Holt HM., Justesen US. 2016. Two Serious Cases of Infection with Clostridium celatum after 40 Years in Hiding? Journal of clinical microbiology 54:236-8. DOI: 10.1128/JCM.01938-15.

Albuquerque L., França L., Rainey FA., Schumann P., Nobre MF., Da Costa MS. 2011. Gaiella occulta gen. nov., sp. nov., a novel representative of a deep branching phylogenetic lineage within the class Actinobacteria and proposal of Gaiellaceae fam. nov. and Gaiellales ord. nov. Systematic and Applied Microbiology 34:595-599. DOI:

10.1016/j.syapm.2011.07.001.

Aminov RI. 2010. A brief history of the antibiotic era: Lessons learned and challenges for the future. Frontiers in Microbiology 1:1-7. DOI: 10.3389/fmicb.2010.00134.

Angelakis E., Bibi F., Ramasamy D., Azhar EI., Jiman-Fatani AA., Aboushoushah SM., Lagier J-C., Robert C., Caputo A., Yasir M., Fournier P-E., Raoult D. 2014. Non-contiguous finished genome sequence and description of Clostridium saudii sp. nov. Standards in Genomic Sciences. DOI: 10.1186/1944-3277-9-8.

Baquero F., Martínez JL., Cantón R. 2008. Antibiotics and antibiotic resistance in water environments. Current Opinion in Biotechnology 19:260-265. DOI:

$$
\text { 10.1016/j.copbio.2008.05.006. }
$$

Bartholomew JW., Paik G. 1966. Isolation and identification of obligate thermophilic sporeforming bacilli from ocean basin cores. Journal of Bacteriology 92:635-638.

Bengtsson-Palme J., Kristiansson E., Larsson DGJ. 2017. Environmental factors influencing the development and spread of antibiotic resistance. FEMS Microbiology Reviews:1-13. DOI: 10.1093/femsre/fux053. 
506 Berendonk TU., Manaia CM., Merlin C., Fatta-Kassinos D., Cytryn E., Walsh F., Bürgmann H.,

507 Sørum H., Norström M., Pons MN., Kreuzinger N., Huovinen P., Stefani S., Schwartz T.,

508 Kisand V., Baquero F., Martinez JL. 2015. Tackling antibiotic resistance: The

509 environmental framework. Nature Reviews Microbiology 13:310-317. DOI:

$510 \quad 10.1038 /$ nrmicro3439.

511 Berg J., Thorsen MK., Holm PE., Jensen J., Nybroe O., Brandt KK. 2010. Cu exposure under

512 field conditions coselects for antibiotic resistance as determined by a novel cultivation-

513 independent bacterial community tolerance assay. Environmental Science \& Technology

$514 \quad 44: 8724-8728$. DOI: 10.1021/es101798r.

515 Berglund B. 2015. Environmental dissemination of antibiotic resistance genes and correlation to 516 anthropogenic contamination with antibiotics. Infection Ecology \& Epidemiology 5:28564.

517 DOI: $10.3402 /$ iee.v5.28564.

518 Bouki C., Venieri D., Diamadopoulos E. 2013. Detection and fate of antibiotic resistant bacteria 519 in wastewater treatment plants: A review. Ecotoxicology and Environmental Safety 91:1-9. $520 \quad$ DOI: $10.1016 /$ j.ecoenv.2013.01.016.

521 Browne HP., Forster SC., Anonye BO., Kumar N., Neville BA., Stares MD., Goulding D., 522 Lawley TD. 2016. Culturing of "unculturable" human microbiota reveals novel taxa and 523 extensive sporulation. Nature 533:543-546. DOI: 10.1038/nature17645.

524 Bueche M. 2014. Spore-forming bacteria as indicators of pollution in sediments of Lake Geneva. $525 \quad$ University of Neuchâtel, Switzerland.

526 Chen B., Liang X., Huang X., Zhang T., Li X. 2013. Differentiating anthropogenic impacts on 527 ARGs in the Pearl River Estuary by using suitable gene indicators. Water Research 528 47:2811-2820. DOI: 10.1016/j.watres.2013.02.042. 
529 Czekalski N., Berthold T., Caucci S., Egli A., Bürgmann H. 2012. Increased levels of

530 multiresistant bacteria and resistance genes after wastewater treatment and their

531 dissemination into Lake Geneva, Switzerland. Frontiers in Microbiology 3:106. DOI:

$532 \quad 10.3389 /$ fmicb.2012.00106.

533 Czekalski N., Gascón Díez E., Bürgmann H. 2014. Wastewater as a point source of antibiotic-

534 resistance genes in the sediment of a freshwater lake. The ISME Journal 8:1381-90. DOI:

$535 \quad$ 10.1038/ismej.2014.8.

536 Devarajan N., Laffite A., Graham ND., Meijer M., Prabakar K., Mubedi JI., Elongo V., Piana

537 PTM., Ibelings BW., Wildi W., Poté J. 2015. Accumulation of Clinically Relevant

538 Antibiotic Resistant Genes, Bacterial load and Metals from a Freshwater Lake Sediments in

539 Central Europe. Environmental Science \& Technology:2015. DOI:

$540 \quad 10.1021 /$ acs.est.5b01031.

541 Dodd MC. 2012. Potential impacts of disinfection processes on elimination and deactivation of

$542 \quad$ antibiotic resistance genes during water and wastewater treatment. Journal of

543 Environmental Monitoring 14:1754-1771. DOI: 10.1039/c2em00006g.

544 Drudge CN. 2012. Prokaryotic Horizontal Gene Transfer in Freshwater Lakes: Implications of

545 Dynamic Biogeochemical Zonation. Journal of Environmental Protection 3:1274-1294.

$546 \quad$ DOI: $10.4236 /$ jep.2012.312181.

547 van Elsas JD., Bailey MJ. 2002. The ecolgy of transfer of mobile genetic elements. FEMS

$548 \quad$ Microb. Ecol. 42:187-197.

549 Federal Office of Public Health and Federal Food Safety and Veterinary Office. 2016. Swiss

550 Antibiotic Resistance Report 2016. Usage of Antibiotics and Occurrence of Antibiotic

$551 \quad$ Resistance in Bacteria from Humans and Animals in Switzerland. 
552 Guo X., Li J., Yang F., Yang J., Yin D. 2014. Prevalence of sulfonamide and tetracycline

553 resistance genes in drinking water treatment plants in the Yangtze River Delta, China.

554 Science of the Total Environment 493:626-631. DOI: 10.1016/j.scitotenv.2014.06.035.

555 Haller L., Tonolla M., Zopfi J., Peduzzi R., Wildi W., Poté J. 2011. Composition of bacterial and

556 archaeal communities in freshwater sediments with different contamination levels (Lake

557 Geneva, Switzerland). Water Research 45:1213-1228. DOI: 10.1016/j.watres.2010.11.018.

558 Herlemann DP., Labrenz M., Jürgens K., Bertilsson S., Waniek JJ., Andersson AF. 2011.

559 Transitions in bacterial communities along the $2000 \mathrm{~km}$ salinity gradient of the Baltic Sea.

$560 \quad$ The ISME Journal 5:1571-1579. DOI: 10.1038/ismej.2011.41.

561 Heuer H., Smalla K. 2007. Manure and sulfadiazine synergistically increased bacterial antibiotic

562 resistance in soil over at least two months. Environmental Microbiology 9:657-666. DOI:

$563 \quad 10.1111 / \mathrm{j} .1462-2920.2006 .01185 . x$.

564 Horn N. 1987. Clostridium disporicum sp. nov., a Saccharolytic Species Able to Form Two

565 Spores per Cell, Isolated from a Rat Cecum. IInternational Journal of Systematic

$566 \quad$ Bacteriology 37:398-401.

567 Hubert C. 2009. A Constant Flux of Diverse Thermophilic Bacteria into the Cold Arctic Seabed.

$568 \quad$ Science 345:1541-1544. DOI: 10.1126/science.1174012.

569 Ji X., Shen Q., Liu F., Ma J., Xu G., Wang Y., Wu M. 2012. Antibiotic resistance gene

570 abundances associated with antibiotics and heavy metals in animal manures and agricultural

571 soils adjacent to feedlots in Shanghai; China. Journal of Hazardous Materials 235-

$572 \quad$ 236:178-185. DOI: 10.1016/j.jhazmat.2012.07.040.

573 Jin L., Kim KK., Baek SH., Lee ST. 2011. Kaistia geumhonensis sp. nov. and Kaistia

574 dalseonensis sp. nov., two members of the class Alphaproteobacteria. International Journal 
of Systematic and Evolutionary Microbiology 61:2577-2581. DOI: 10.1099/ijs.0.028894-0.

576

577

578

579

580

581

582

583

584

585

586

587

588

589

590

591

592

593

594

595

596

597

Kenzaka T., Tani K., Nasu M. 2010. High-frequency phage-mediated gene transfer in freshwater environments determined at single-cell level. ISME Journal 4:648-659. DOI: 10.1038/ismej.2009.145.

Klieve A V., O’Leary MN., McMillen L., Ouwerkerk D. 2007. Ruminococcus bromii, identification and isolation as a dominant community member in the rumen of cattle fed a barley diet. Journal of Applied Microbiology 103:2065-2073. DOI: 10.1111/j.13652672.2007.03492.x.

Knapp CW., McCluskey SM., Singh BK., Campbell CD., Hudson G., Graham DW. 2011. Antibiotic resistance gene abundances correlate with metal and geochemical conditions in archived Scottish soils. PLoS ONE 6. DOI: 10.1371/journal.pone.0027300.

Kozich JJ., Westcott SL., Baxter NT., Highlander SK., Schloss PD. 2013. Development of a dual-index sequencing strategy and curation pipeline for analyzing amplicon sequence data

on the miseq illumina sequencing platform. Applied and Environmental Microbiology 79:5112-5120. DOI: 10.1128/AEM.01043-13.

Lamendella R., Santo Domingo JW., Kelty C., Oerther DB. 2008. Bifidobacteria in feces and environmental waters. Applied and Environmental Microbiology 74:575-584. DOI:

10.1128/AEM.01221-07.

LaPara TM., Burch TR., McNamara PJ., Tan DT., Yan M., Eichmiller JJ. 2011. Tertiary-treated municipal wastewater is a significant point source of antibiotic resistance genes into DuluthSuperior Harbor. Environmental Science \& Technology 45:9543-9549. DOI: $10.1021 / \mathrm{es} 202775 \mathrm{r}$.

Lennon JT., Jones SE. 2011. Microbial seed banks: the ecological and evolutionary implications 
of dormancy. Nature Reviews Microbiology 9:119-130. DOI: 10.1038/nrmicro2504.

599 Leser TD., Amenuvor JZ., Jensen TK., Lindecrona RH., Boye M., Moøller K. 2002. Culture-

600 independent analysis of gut bacteria: The pig gastrointestinal tract microbiota revisited.

601 Applied and Environmental Microbiology 68:673-690. DOI: 10.1128/AEM.68.2.673-

$602 \quad 690.2002$.

603 Lozupone CA., Stombaugh JI., Gordon JI., Jansson JK., Knight R. 2012. Diversity , stability and 604 resilience of the human gut microbiota. Nature 489:220-230. DOI: 10.1038/nature11550.

605 Madigan MT., Martinko J., Bender K., Buckley D., Stahl D. 2015. Brock Biology of 606 Microorganisms. Boston : Pearson.

607 Madueño L., Paul C., Junier T., Bayrychenko Z., Filippidou S., Beck K., Greub G., Bürgmann 608 H., Junier P. 2018. A historical legacy of antibiotic utilization on bacterial seed banks in 609 sediments. PeerJ 6:e4197. DOI: 10.7717/peerj.4197.

610 Marti E., Variatza E., Balcazar JL. 2014. The role of aquatic ecosystems as reservoirs of 611 antibiotic resistance. Trends in Microbiology 22:36-41. DOI: 10.1016/j.tim.2013.11.001.

612 McMurdie PJ., Holmes S. 2013. Phyloseq: An R Package for Reproducible Interactive Analysis 613 and Graphics of Microbiome Census Data. PLoS ONE 8. DOI:

$614 \quad$ 10.1371/journal.pone.0061217.

615 Moore WEC., Cato EP., Holdeman L V. 1972. Ruminococcus bromii sp. n. and Emendation of 616 the Description of Ruminococcus Sijpestein. International Journal of Systematic $617 \quad$ Bacteriology 22:78-80.

618 Mukhopadhya I., Moraïs S., Laverde-Gomez J., Sheridan PO., Walker AW., Kelly W., Klieve A 619 V., Ouwerkerk D., Duncan SH., Louis P., Koropatkin N., Cockburn D., Kibler R., Cooper 620 PJ., Sandoval C., Crost E., Juge N., Bayer EA., Flint HJ. 2018. Sporulation capability and 
621

622

623

624

625

626

627

628

629

630

631

632

633

634

635

636

637

638

639

640

641

642

643

amylosome conservation among diverse human colonic and rumen isolates of the keystone starch-degrader Ruminococcus bromii. Environmental Microbiology 20:324-336. DOI: 10.1111/1462-2920.14000.

Munir M., Wong K., Xagoraraki I. 2011. Release of antibiotic resistant bacteria and genes in the effluent and biosolids of five wastewater utilities in Michigan. Water Research 45:681-693.

DOI: $10.1016 /$ j.watres.2010.08.033.

Na G., Zhang W., Zhou S., Gao H., Lu Z., Wu X., Li R., Qiu L., Cai Y., Yao Z. 2014.

Sulfonamide antibiotics in the Northern Yellow Sea are related to resistant bacteria: Implications for antibiotic resistance genes. Marine Pollution Bulletin 84:70-75. DOI:

10.1016/j.marpolbul.2014.05.039.

O’Neill J. 2015. Tackling a Crisis for the Health and Wealth of Nations. The Review on Antimicrobial Resistance. DOI: 10.1038/510015a.

Oksanen J., Blanchet FG., Friendly M., Kindt R., Legendre P., McGlinn D., Minchin PR., O’Hara RB., Simpson GL., Solymos P., Stevens MHH., Szoecs E., Wagner H. 2017. vegan: Community Ecology Package.

Perry JA., Westman EL., Wright GD. 2014. The antibiotic resistome: What's new? Current Opinion in Microbiology 21:45-20. DOI: 10.1016/j.mib.2014.09.002.

Popoff MR., Bouvet P. 2009. Clostridial toxins. Future Microbiology 4:1021-1064. DOI: 10.2217/FMB.09.72.

Quast C., Pruesse E., Yilmaz P., Gerken J., Schweer T., Yarza P., Peplies J., Glöckner FO. 2013. The SILVA ribosomal RNA gene database project: Improved data processing and webbased tools. Nucleic Acids Research 41:590-596. DOI: 10.1093/nar/gks1219.

R Core Team. 2014. R: A Language and Environment for Statistical Computing. 
644 de Rezende JR., Kjeldsen KU., Hubert CRJ., Finster K., Loy A., Jørgensen BB. 2013. Dispersal

645 of thermophilic Desulfotomaculum endospores into Baltic Sea sediments over thousands of 646 years. The ISME Journal 7:72-84. DOI: 10.1038/ismej.2012.83.

647 Rizzo L., Manaia C., Merlin C., Schwartz T., Dagot C., Ploy MC., Michael I., Fatta-Kassinos D. 648 2013. Urban wastewater treatment plants as hotspots for antibiotic resistant bacteria and 649 genes spread into the environment: A review. Science of the Total Environment 447:345650 360. DOI: 10.1016/j.scitotenv.2013.01.032.

651 Roberts MC. 1996. Tetracycline resistance determinants: mechanisms of action, regulation of 652 expression, genetic mobility, and distribution. FEMS microbiology reviews 19:1-24. DOI: 10.1016/0168-6445(96)00021-6.

654

655

656

657

658

659

660

661

662

663

664

665

666

Rodriguez-Mozaz S., Chamorro S., Marti E., Huerta B., Gros M., Sànchez-Melsió A., Borrego CM., Barceló D., Balcázar JL uis. 2015. Occurrence of antibiotics and antibiotic resistance genes in hospital and urban wastewaters and their impact on the receiving river. Water research 69:234-242. DOI: 10.1016/j.watres.2014.11.021.

Saia FT., Souza TSO., Duarte RTD., Pozzi E., Fonseca D., Foresti E. 2016. Microbial community in a pilot-scale bioreactor promoting anaerobic digestion and sulfur-driven denitrification for domestic sewage treatment. Bioprocess and Biosystems Engineering 39:341-352. DOI: 10.1007/s00449-015-1520-6.

Salyers AA., Gupta A., Wang YP. 2004. Human intestinal bacteria as reservoirs for antibiotic resistance genes. Trends in Microbiology 12:412-416. DOI: 10.1016/j.tim.2004.07.004.

Sauvain L., Bueche M., Junier T., Masson M., Wunderlin T., Kohler-Milleret R., Gascon Diez E., Loizeau J-L., Tercier-Waeber M Lou., Junier P. 2014. Bacterial communities in trace metal contaminated lake sediments are dominated by endospore-forming bacteria. Aquatic 
667

668

669

670

671

672

673

674

675

676

677

678

679

680

681

682

683

684

685

686

687

688

689

Sciences 76:33-46. DOI: 10.1007/s00027-013-0313-8.

van Schaik W. 2015. The human gut resistome. Philosophical Transactions of the Royal Society B: Biological Sciences 370:20140087-20140087. DOI: v.

Schleifer KH. 2009. Phylum XIII. Firmicutes Gibbons and Murray 1978, 5 (Firmacutes [sic] Gibbons and Murray 1978, 5). In: De Vos P, Garrity GM, Jones D, Krieg N, Ludwig W, Rainey F, Schleifer K-H, Whitman W eds. Bergey's Manual of Systematic Bacteriology Volume 3. Dordrecht Heidelberg London New York: Springer, 19-1317.

Schloss PD., Westcott SL., Ryabin T., Hall JR., Hartmann M., Hollister EB., Lesniewski RA., Oakley BB., Parks DH., Robinson CJ., Sahl JW., Stres B., Thallinger GG., Van Horn DJ., Weber CF. 2009. Introducing mothur: Open-source, platform-independent, communitysupported software for describing and comparing microbial communities. Applied and Environmental Microbiology 75:7537-7541. DOI: 10.1128/AEM.01541-09.

Schmidt B., Mulder IE., Musk CC., Aminov RI., Lewis M., Stokes CR., Bailey M., Prosser JI., Gill BP., Pluske JR., Kelly D. 2011. Establishment of normal gut microbiota is compromised under excessive hygiene conditions. PLOS ONE 6. DOI: 10.1371/journal.pone.0028284.

Shoemaker WR., Lennon JT. 2018. Evolution with a seed bank: The population genetic consequences of microbial dormancy. Evolutionary Applications 11:60-75. DOI: 10.1111/eva.12557.

Sköld O. 2001. Resistance to trimethoprim and sulfonamides. Veterinary Research 32:261-273. DOI: $10.1051 /$ vetres:2001123.

Sommer MOA., Dantas G., Church GM. 2009. Functional Characterization of the Antibiotic Resistance Reservoir in the Human Microflora. Science 325:1128-1131. DOI: 
691 Spigaglia P., Barbanti F., Mastrantonio P. 2008. Tetracycline resistance gene tet(W) in the 692 pathogenic bacterium Clostridium difficile. Antimicrobial Agents and Chemotherapy $693 \quad 52: 770-773$. DOI: 10.1128/AAC.00957-07.

694 Szczepanowski R., Linke B., Krahn I., Gartemann KH., Gützkow T., Eichler W., Pühler A., 695 Schlüter A. 2009. Detection of 140 clinically relevant antibiotic-resistance genes in the 696 plasmid metagenome of wastewater treatment plant bacteria showing reduced susceptibility 697 to selected antibiotics. Microbiology 155:2306-2319. DOI: $10.1099 / \mathrm{mic} .0 .028233-0$. 698 Taylor NGH., Verner-Jeffreys DW., Baker-Austin C. 2011. Aquatic systems: Maintaining, 699 mixing and mobilising antimicrobial resistance? Trends in Ecology and Evolution 26:278700 284. DOI: $10.1016 /$ j.tree.2011.03.004.

701 Tetz G., Tetz V. 2017. Introducing the sporobiota and sporobiome. Gut Pathogens 9:1-6. DOI: 10.1186/s13099-017-0187-8.

703

704

705

706

707

708

709

710

711

712

Thevenon F., Adatte T., Wildi W., Poté J. 2012. Antibiotic resistant bacteria/genes dissemination in lacustrine sediments highly increased following cultural eutrophication of Lake Geneva (Switzerland). Chemosphere 86:468-476. DOI: 10.1016/j.chemosphere.2011.09.048.

Thorasin T., Hoyles L., McCartney AL. 2015. Dynamics and diversity of the "Atopobium cluster" in the human faecal microbiota, and phenotypic characterization of "Atopobium cluster” isolates. Microbiology (Reading, England) 161:565-579. DOI: 10.1099/mic.0.000016.

Vandewalle JL., Goetz GW., Huse SM., Morrison HG., Sogin ML., Hoffmann RG., Yan K., Mclellan SL. 2012. Acinetobacter, Aeromonas and Trichococcus populations dominate the microbial community within urban sewer infrastructure. Environmental Microbiology 
714

715

716

717

718

719

720

721

722

723

724

725

726

727

728

729

730

731

732

733

734

735

de Vries LE., Vallès Y., Agersø Y., Vaishampayan PA., García-Montaner A., Kuehl J V., Christensen H., Barlow M., Francino MP. 2011. The gut as reservoir of antibiotic resistance: Microbial diversity of tetracycline resistance in mother and infant. PLoS ONE 6 . DOI: 10.1371/journal.pone.0021644.

Walsh F., Ingenfeld A., Zampicolli M., Hilber-Bodmer M., Frey JE., Duffy B. 2011. Real-time PCR methods for quantitative monitoring of streptomycin and tetracycline resistance genes in agricultural ecosystems. Journal of Microbiological Methods 86:150-155. DOI: 10.1016/j.mimet.2011.04.011.

Wang RF., Cao WW., Cerniglia CE. 1997. PCR detection of Ruminococcus spp. in human and animal faecal samples. Molecular and Cellular Probes 11:259-265. DOI: 10.1006/mcpr.1997.0111.

Wang Z., Zhang X-X., Huang K., Miao Y., Shi P., Liu B., Long C., Li A. 2013. Metagenomic Profiling of Antibiotic Resistance Genes and Mobile Genetic Elements in a Tannery Wastewater Treatment Plant. PLoS ONE 8:e76079. DOI: 10.1371/journal.pone.0076079.

Wunderlin T., Junier T., Roussel-Delif L., Jeanneret N., Junier P. 2013. Stage 0 sporulation gene A as a molecular marker to study diversity of endospore-forming Firmicutes. Environmental Microbiology Reports 5:911-924. DOI: 10.1111/1758-2229.12094.

Wunderlin T., Junier T., Roussel-Delif L., Jeanneret N., Junier P. 2014. Endospore-enriched sequencing approach reveals unprecedented diversity of Firmicutes in sediments. Environmental Microbiology Reports 6:631-639. DOI: 10.1111/1758-2229.12179.

Xu J., Xu Y., Wang H., Guo C., Qiu H., He Y., Zhang Y., Li X., Meng W. 2015. Occurrence of antibiotics and antibiotic resistance genes in a sewage treatment plant and its effluent- 
receiving river. Chemosphere 119:1379-1385. DOI: 10.1016/j.chemosphere.2014.02.040.

737 Yamada T., Sekiguchi Y., Hanada S., Imachi H., Ohashi A., Harada H., Kamagata Y. 2006.

738 Anaerolinea thermolimosa sp. nov., Levilinea saccharolytica gen. nov., sp. nov. and

739 Leptolinea tardivitalis gen. nov., sp. nov., novel filamentous anaerobes, and description of

740 the new classes Anaerolineae classis nov. and Caldilineae classis nov. in the . International

$741 \quad$ Journal of Systematic and Evolutionary Microbiology 56:1331-1340. DOI:

$742 \quad$ 10.1099/ijs.0.64169-0.

743 Zhang Y., Geng J., Ma H., Ren H., Xu K., Ding L. 2016. Characterization of microbial

744 community and antibiotic resistance genes in activated sludge under tetracycline and

745 sulfamethoxazole selection pressure. Science of the Total Environment 571:479-486. DOI:

$746 \quad$ 10.1016/j.scitotenv.2016.07.014.

747

748 


\section{Figure Legends}

750

751 Figure 1. Map indicating the sampling locations in the Vidy Bay, Lake Geneva, Switzerland.

752 Samples were retrieved from three zones differently impacted by the wastewater treatment plant

753 (WWTP). Red circles are for the distal zone (D; 611-956 m from the outlet pipe), green circles

754 are for the middle zone $(\mathrm{M} ; 134-429 \mathrm{~m})$, and blue circle are for the near zone $(\mathrm{N} ; 5-40 \mathrm{~m})$. Outlet

755 pipe of the WWTP is represented by the black line. The original maps were obtained from

756 www.swisstopo.ch, owners of the copyright of the image.

757

758

Figure 2. Boxplots for tet(W) and sull distribution in the samples from distal (D), middle (M)

759

760

761

762

763

764

765

766

767

768

769

770

771

772 and near $(\mathrm{N})$ sampling zones. A. tet $(\mathrm{W}) \log$-transformed gene abundance (copies/g of sediment). B. tet(W) log-transformed gene frequency (copies/ng DNA). C. sull log-transformed gene abundance (copies/g of sediment). D. sul1 log-transformed gene frequency (copies/ng DNA). Pairwise comparison with Tuckey's test was performed to compare the ARG level between the zones (Distal-Middle, Distal-Near, Middle-Near). Significance codes of $p$-values: $0<* * *<$ $0.001<* *<0.01<*<0.05<.<0.1$. (n.s.) stands for "not significant".

Figure 3. Composition of the sporobiota community in sediments from Vidy Bay (Lake Geneva) based on 16S rRNA gene amplicon sequencing. Relative abundance of the most abundant genera $(>0.2 \%$ of the total community) is represented.

Figure 4. Principal coordinates analysis (PCoA) triplot of the samples, based on Bray-Curtis dissimilarity and Hellinger transformation of the OTU table. OTUs represented by less than 4 sequences in the whole dataset were removed from the analysis. OTUs were classified at genus 
773 level (or higher taxonomic rank if not possible). Colors and symbols correspond to different

774 orders. For better readability only the 500 most abundant OTUs belonging to the main classes

$775\left(>0.1 \%\right.$ of the sporobiota community) are shown. Environmental variables (including $\mathrm{C}_{\text {org }}, \mathrm{N}_{\text {tot }}$,

776 trace and heavy metals (TMs), the distance to the outlet pipe (Dist pipe), DNA abundance in

777 ng/g sediment (DNA_ng_gSed), and ARG abundance (cp_gSed) and frequency (cp_ng)) were

778 standardized and passively fitted to the ordination. Only significant parameters were displayed

$779(p<0.05)$. Values for $\mathrm{C}_{\text {org }}, \mathrm{N}_{\text {tot }}$, and TMs were obtained from previous studies (Bueche, 2014;

780 Sauvain et al., 2014).

781

782 Figure 5. Kernel density curves representing the frequency of the Spearman's correlation 783 coefficients calculated between ARG and OTU and relative abundance of the 10 most positively 784 correlated OTUs for each ARG. A. Kernel density curves for tet(W). B. Kernel density curves 785 for sul1. C. Relative abundance of OTUs correlated with tet(W). D. Relative abundance of OTUs 786 correlated with sul1. 
788 Tables

789

790 Table 1. Abundance (copies/g of sediment) and frequency (copies/ng of DNA) of two antibiotic

791 resistance genes (tet(W) and sul1) in the sporobiota, in sediments samples from the Vidy Bay

792 (Lake Geneva, CH).

793

794 Table 2. Correlations between OTU relative abundance and ARG frequency. Each line indicates

795 the correlation coefficient of the 10 most positively correlated OTUs, their associated $\boldsymbol{p}$-values

796 (with and without adjustment for multiple comparison) and the phylogenetic identity of OTUs.

797 Adjusted $\boldsymbol{p}$-value were calculated using the Benjamini-Hochberg method to control the false

798 discovery rate.

799 


\section{Supplementary Figure Legends}

801

802 Supplementary Figure 1. (A) Biplot representing the ARG abundance (copies/g sediment, 803 above) and frequency (copies/ng DNA, below) in each sample. (B) Principal component analysis 804 (PCA, scaling 2) on the environmental parameters, including $\mathrm{C}_{\text {org }}, \mathrm{N}_{\text {tot }}$, trace and heavy metals 805 (TMs), the distance to the outlet pipe (Dist_pipe), DNA abundance in ng/g sediment 806 (DNA_ng_gSed), and ARG abundance (cp_gSed) and frequency (cp_ng). Arrows represent the 807 contribution of variables to the axis, and angles between variables reflect their correlations. 808 Colors correspond to the three sampling zones: near, middle and distal. Values for $\mathrm{C}_{\text {org }}, \mathrm{N}_{\text {tot }}$, and 809 TMs were obtained from previous studies (Bueche, 2014; Sauvain et al., 2014).

810

811 Supplementary Figure 2. Linear regressions of log-transformed ARG abundance (left) and 812 frequency (right), on the distance to the WWTP outlet pipe (m). Linear regressions calculated for 813 (A) tet(W) and (B) sul1. Blue circles and lines correspond to the samples from the upper 814 sediment. Red circles and lines correspond to the samples from the lower sediment. Black lines 815 correspond to samples all together. Significance of the models was tested by analysis of variance 816 (ANOVA). Significance codes of p-values: $0<* * *<0.00$. (n.s.) stands for "not significant".

818 Supplementary Figure 3. Spearman's correlations coefficient with significance levels for all 819 pairwise comparisons between $\mathrm{C}_{\text {org }}, \mathrm{N}_{\text {tot }}$, TMs, and $\mathrm{ARG}$ abundance and frequency. Values for

$820 \mathrm{C}_{\text {org }}, \mathrm{N}_{\text {tot }}$, and TMs were obtained from previous studies (Bueche, 2014; Sauvain et al., 2014).

821 Significance codes of p-values: $0<* * *<0.001<* *<0.01<*<0.05<.<0.1$. 
823 Supplementary Figure 4. Composition of the sporobiota community at phylum level, in

824 sediments from the Vidy Bay (Lake Geneva), based on 16S rRNA sequencing. Only taxa

825 accounting for at least $0.1 \%$ of the total community are shown. Firmicutes was the dominant

826 phylum accounting for at least $85.2 \%$ of the sporobiome community. The other main phyla

827 detected corresponded to Proteobacteria (3.81\%), Actinobacteria (2.95\%), Chloroflexi (0.44\%),

828 Planctomycetes $(0.22 \%)$, and Cyanobacteria $(0.16 \%)$.

829

830 Supplementary Figure 5. Principal coordinates analysis (PCoA) triplot of the samples, based on

831 Bray-Curtis dissimilarity and Hellinger transformation of the OTU table. OTUs including less

832 than 4 sequences in the whole dataset were removed from the analysis. OTUs were classified at 833 genus level (or higher taxonomic rank if not possible). Colors and symbols correspond to 834 different classes. The 500 most abundant OTUs are shown.

836 Supplementary Dataset. Raw data including the sediment depth layer, distance to the outlet 837 pipeline and concentrations of organic carbon $\left(\mathrm{C}_{\text {org }}\right)$, total nitrogen $\left(\mathrm{Nt}_{\mathrm{ot}}\right)$, of cadmium $(\mathrm{Cd})$, 838 copper $(\mathrm{Cu})$, iron $(\mathrm{Fe})$, manganese $(\mathrm{Mn})$, aluminum $(\mathrm{Al})$, zinc $(\mathrm{Zn})$, and arsenic (As).

839

840 Other supplementary files. Blastp results for Tet(W) (file BLASTP-results_Tet(W)) and Sul1 841 (file BLASTP-results_Sul1). 
Figure 1

Map indicating the sampling locations in the Vidy Bay, Lake Geneva, Switzerland.

Samples were retrieved from three zones differently impacted by the wastewater treatment plant (WWTP). Red circles are for the distal zone (D; 611-956 m from the outlet pipe), green circles are for the middle zone ( $\mathrm{M} ; 134-429 \mathrm{~m})$, and blue circle are for the near zone (N; 5-40 $\mathrm{m})$. Outlet pipe of the WWTP is represented by the black line. The original maps were obtained from www.swisstopo.ch, owners of the copyright of the image.

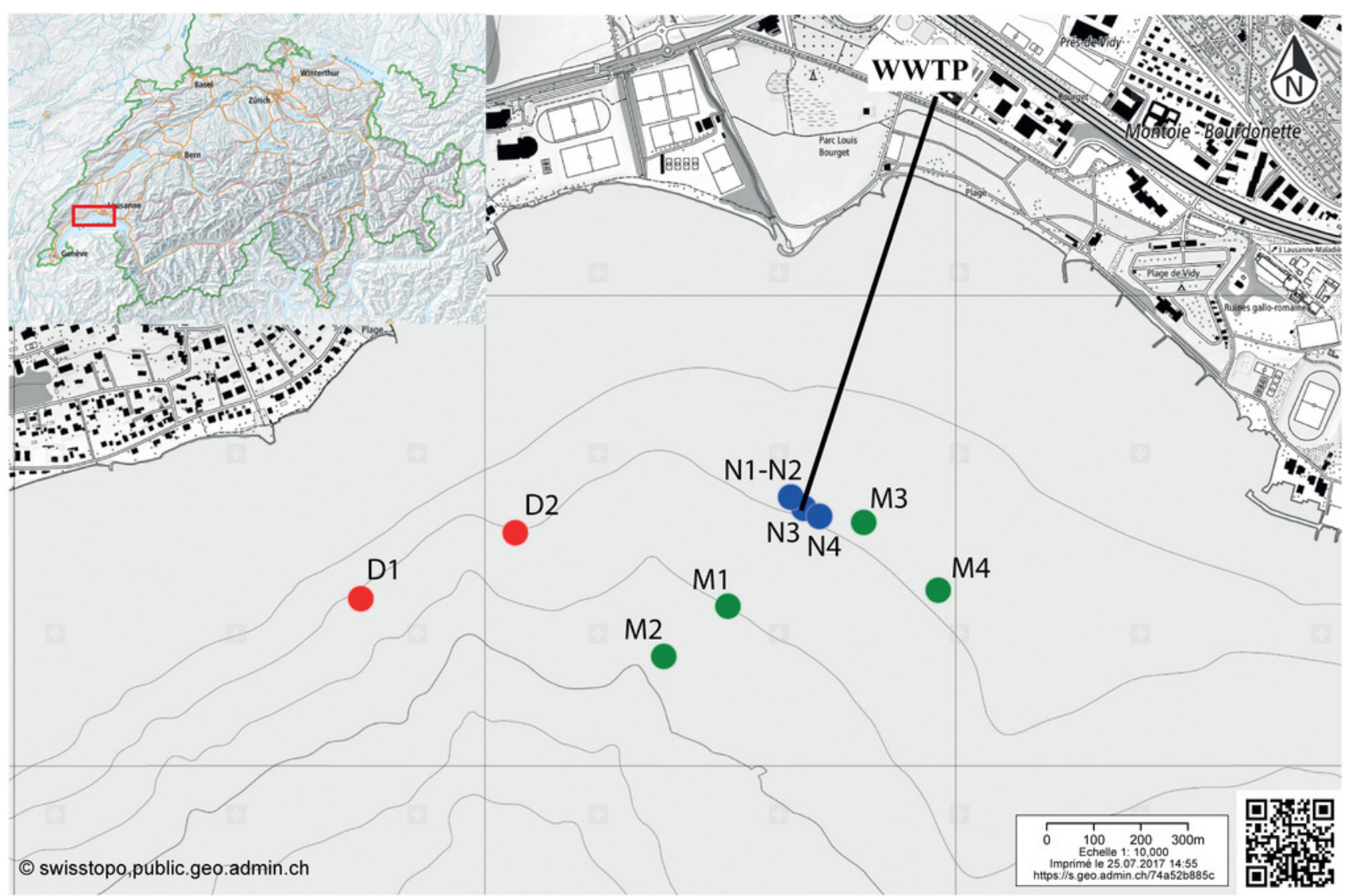


Figure 2 (on next page)

Abundance and frequency of ARG in relationship to distance to the wastewater treatment plant.

Boxplots for (A) tet(W) and (B) sul1 distribution in the samples from distal (D), middle (M) and near (N) sampling zones. On the left, log-transformed genes abundance (copies of genes/g of sediment). On the right, log-transformed genes frequency (copies of genes/ng DNA).

Significance value of the global model is shown, as well as between the zones (Distal-Middle, Distal-Near, Middle-Near). Significance codes of p-values: $0<* * * 0.001<* *<0.01<*<$ $0.05<$. $<0.1$. (n.s.) stands for "not significant". 


\section{Figure 3 (on next page)}

Characterization of the sporobiome community in sediments.

Composition of the sporobiome community in sediments from Vidy Bay (Lake Geneva) based on $16 \mathrm{~S}$ rRNA gene amplicon sequencing. Relative abundance of the most abundant genera ( $>0.2 \%$ of the total community) is represented. 


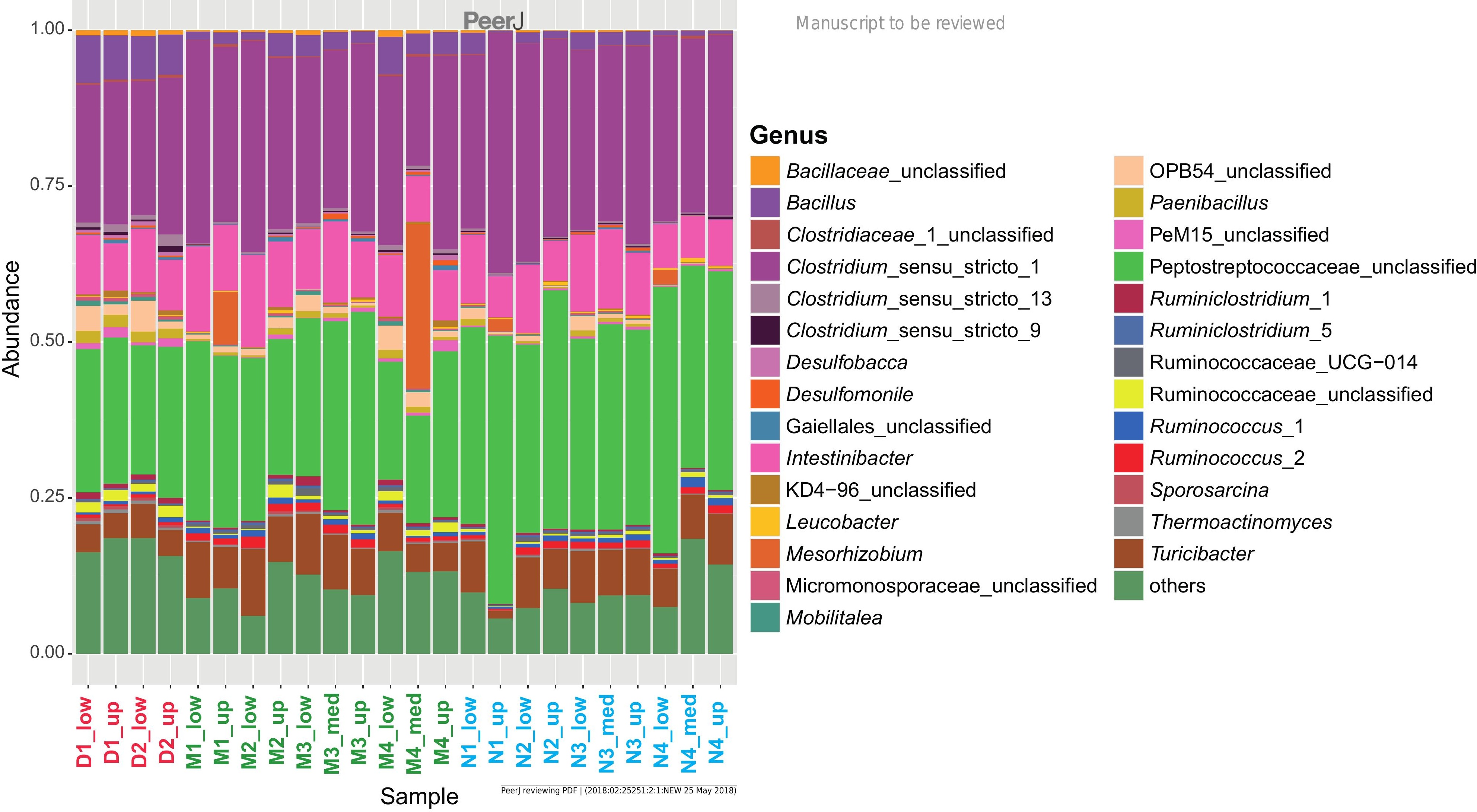




\section{Figure 4 (on next page)}

Principal coordinates analysis (PCoA) triplot of the sediment samples based on BrayCurtis dissimilarity and Hellinger transformation of the OTU table.

OTUs represented by less than 4 sequences in the whole dataset were removed from the analysis. OTUs were classified at genus level (or higher taxonomic rank if not possible).

Colors correspond to different orders. Only the 80 most abundant OTUs are shown.

Environmental variables (including $\mathrm{C}_{\text {org }} \mathrm{N}_{\text {tot }}$ trace and heavy metals (TMs), the distance to the outlet pipe (Dist_pipe), DNA abundance in ng/g sediment (DNA_ng_gSed), and ARG abundance (cp_gSed) and frequency (cp_ng)) were standardized and passively fitted to the ordination. Only significant parameters were displayed $(p<0.05)$. Values for $\mathrm{C}_{\text {org }}, \mathrm{N}_{\text {tot }}$, and TMs were obtained from previous studies (Bueche, 2014; Sauvain et al., 2014) . 


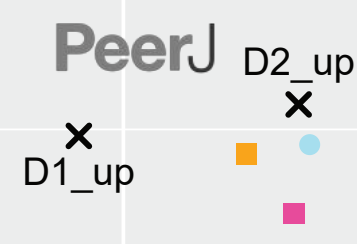

0.1

$0.0-$

$\stackrel{\mathrm{D} 2 \text { low }}{\times} \times$

$x$ M4 low

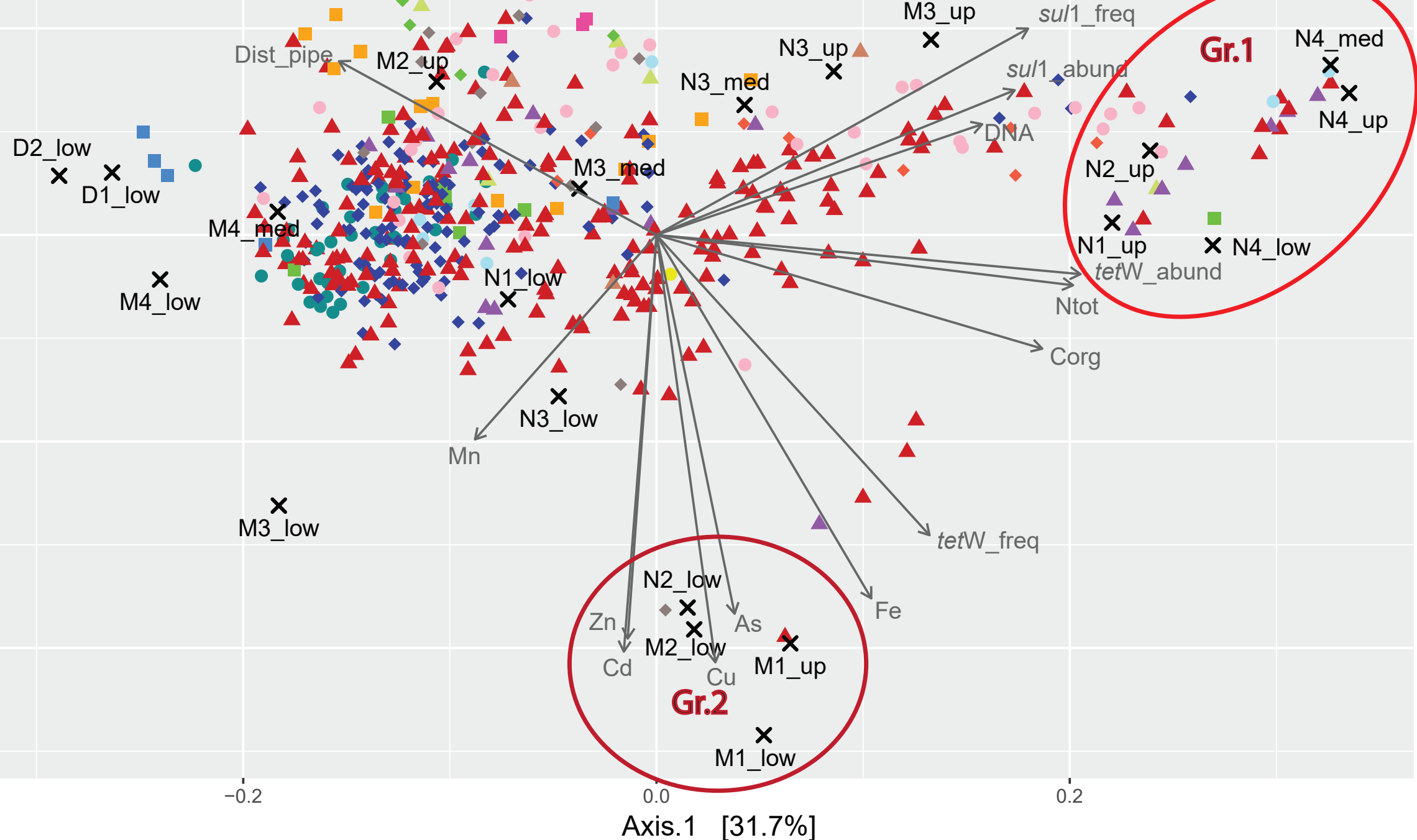

Class

- Acidimicrobiia

- Actinobacteria

- Alphaproteobacteria

- Bacilli

- Bacteria_unclassified
- Clostridia

- Coriobacteriia

- Deltaproteobacteria

- Erysipelotrichia

$\triangle$ Gammaproteobacteria

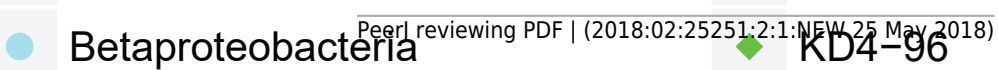


Figure 5 (on next page)

Correlation between specific OTU and frequency of the ARG tet(W) and sul1

(A) Kernel density curves representing the frequency of the Spearman's correlation coefficients calculated between each ARG and OTU. (B) Relative abundance of the 10 most positively correlated OTUs for each ARG. 


\section{Table $\mathbf{1}$ (on next page)}

Abundance and frequency of antibiotic resistance genes in sediments

Abundance (copies/g of sediment) and frequency (copies/ng of DNA) of two antibiotic resistance genes (tet(W) and sul1) in the sporobiome DNA, in sediments samples from the Vidy Bay (Lake Geneva, $\mathrm{CH}$ ). 


\begin{tabular}{|c|c|c|c|c|c|c|c|}
\hline \multirow[t]{2}{*}{ Sample } & \multirow{2}{*}{$\begin{array}{l}\text { Sediment depth } \\
(\mathrm{cm})\end{array}$} & \multirow{2}{*}{$\begin{array}{l}\text { Dist. to the pipe } \\
\qquad(\mathrm{m})\end{array}$} & \multirow{2}{*}{$\begin{array}{c}\text { DNA } \\
\text { (ng/g sed) }\end{array}$} & \multicolumn{2}{|c|}{ tet(W) } & \multicolumn{2}{|c|}{ sul1 } \\
\hline & & & & (copies/ng DNA) & (copies/g sed) & (copies/ng DNA) & (copies/g sed) \\
\hline D1_low & $3-9$ & 955.89 & 3.081 & $3.01 E+03$ & $9.26 \mathrm{E}+03$ & $4.65 E+01$ & $1.43 E+02$ \\
\hline D1_up & $0-3$ & 955.89 & 5.385 & $2.81 E+03$ & $1.51 E+04$ & $9.33 E+01$ & $5.02 E+02$ \\
\hline D2_low & $3-9$ & 610.99 & 2.461 & $3.73 E+03$ & $9.19 E+03$ & $5.17 \mathrm{E}+01$ & $1.27 \mathrm{E}+02$ \\
\hline D2_up & $0-3$ & 610.99 & 3.805 & $3.27 E+03$ & $1.24 \mathrm{E}+04$ & $8.58 \mathrm{E}+01$ & $3.26 \mathrm{E}+02$ \\
\hline M1_low & $3-9$ & 259.15 & 3.066 & $2.56 \mathrm{E}+04$ & $7.85 E+04$ & $2.29 E+02$ & $7.02 E+02$ \\
\hline M1_up & $0-3$ & 259.15 & 3.530 & $1.19 E+04$ & $4.19 E+04$ & $3.22 E+02$ & $1.14 \mathrm{E}+03$ \\
\hline M2_low & $3-9$ & 429.04 & 2.391 & $2.50 E+04$ & $5.98 E+04$ & $1.78 \mathrm{E}+02$ & $4.25 E+02$ \\
\hline M2_up & $0-3$ & 429.04 & 2.166 & $1.19 E+04$ & $2.58 E+04$ & $3.82 E+02$ & $8.26 \mathrm{E}+02$ \\
\hline M3_low & $3-9$ & 133.76 & 0.773 & $7.37 E+03$ & $5.69 E+03$ & $2.80 E+01$ & $2.17 \mathrm{E}+01$ \\
\hline M3_med & $1.5-3$ & 133.76 & 1.104 & $9.56 \mathrm{E}+03$ & $1.06 \mathrm{E}+04$ & $1.75 E+02$ & $1.93 E+02$ \\
\hline M3_up & $0-1.5$ & 133.76 & 2.963 & $1.38 \mathrm{E}+04$ & $4.10 E+04$ & $4.97 E+02$ & $1.47 \mathrm{E}+03$ \\
\hline M4_low & $3-9$ & 335.80 & 0.968 & $8.85 E+03$ & $8.57 E+03$ & $1.65 \mathrm{E}+02$ & $1.60 \mathrm{E}+02$ \\
\hline M4_med & $1.5-3$ & 335.80 & 1.958 & $2.43 E+03$ & $4.75 E+03$ & $6.56 \mathrm{E}+01$ & $1.28 \mathrm{E}+02$ \\
\hline M4_up & $0-1.5$ & 335.80 & 1.208 & $8.93 E+03$ & $1.08 \mathrm{E}+04$ & $5.83 E+02$ & $7.04 \mathrm{E}+02$ \\
\hline N1_low & $3-9$ & 5.39 & 2.313 & $7.24 E+03$ & $1.67 E+04$ & $1.26 \mathrm{E}+02$ & $2.92 E+02$ \\
\hline N1_up & $0-3$ & 5.39 & 4.802 & $1.21 \mathrm{E}+04$ & $5.79 E+04$ & $3.21 E+02$ & $1.54 \mathrm{E}+03$ \\
\hline N2_low & $3-9$ & 5.39 & 4.183 & $1.46 \mathrm{E}+04$ & $6.12 E+04$ & $2.32 E+02$ & $9.69 E+02$ \\
\hline N2_up & $0-3$ & 5.39 & 7.658 & $1.81 E+04$ & $1.38 \mathrm{E}+05$ & $6.20 \mathrm{E}+02$ & $4.75 E+03$ \\
\hline N3_low & $3-9$ & 36.14 & 2.497 & $1.31 \mathrm{E}+04$ & $3.27 E+04$ & $1.57 \mathrm{E}+02$ & $3.92 \mathrm{E}+02$ \\
\hline N3_med & $1.5-3$ & 36.14 & 2.428 & $1.36 \mathrm{E}+04$ & $3.31 E+04$ & $4.08 E+02$ & $9.90 E+02$ \\
\hline N3_up & $0-1.5$ & 36.14 & 2.617 & $1.29 \mathrm{E}+04$ & $3.38 \mathrm{E}+04$ & $4.18 \mathrm{E}+02$ & $1.09 E+03$ \\
\hline N4_low & $3-9$ & 39.61 & 13.900 & $1.14 \mathrm{E}+04$ & $1.58 \mathrm{E}+05$ & $7.80 \mathrm{E}+02$ & $1.08 \mathrm{E}+04$ \\
\hline N4_med & $1.5-3$ & 39.61 & 10.515 & $1.72 E+04$ & $1.81 \mathrm{E}+05$ & $1.34 \mathrm{E}+03$ & $1.41 E+04$ \\
\hline N4_up & $0-1.5$ & 39.61 & 7.115 & $1.92 \mathrm{E}+04$ & $1.37 E+05$ & $1.60 E+03$ & $1.14 \mathrm{E}+04$ \\
\hline
\end{tabular}




\section{Table 2 (on next page)}

Correlations between OTU relative abundance and ARG frequency.

Each line indicate the correlation coefficient of the 10 most positively and negatively correlated OTUs and their phylogenetic identity. 
1

\begin{tabular}{|c|c|c|c|c|c|}
\hline \multicolumn{6}{|c|}{$\operatorname{tet}(\mathrm{W})$} \\
\hline OTU & cor. coeff. & p-value & adj.p-value & Phylum & Genus \\
\hline Otu00045 & 0.841 & $2.58 \mathrm{E}-07$ & 8.23E-04 & Firmicutes & Ruminococcus_1 \\
\hline Otu00002 & 0.805 & 2.10E-06 & $1.47 \mathrm{E}-03$ & Firmicutes & Clostridium_sensu_stricto_1 \\
\hline Otu00062 & 0.712 & $9.42 \mathrm{E}-05$ & $1.06 \mathrm{E}-02$ & Firmicutes & Ruminococcus_1 \\
\hline Otu00090 & 0.673 & 3.09E-04 & $2.15 E-02$ & Synergistetes & Synergistaceae_unclassified \\
\hline Otu00823 & 0.673 & 3.13E-04 & $2.15 E-02$ & Actinobacteria & Georgenia \\
\hline Otu01955 & 0.667 & $3.66 \mathrm{E}-04$ & $2.32 \mathrm{E}-02$ & Proteobacteria & Kaistia \\
\hline Otu01188 & 0.663 & 4.19E-04 & $2.50 \mathrm{E}-02$ & Actinobacteria & Tessaracoccus \\
\hline Otu00092 & 0.651 & 5.64E-04 & $2.91 \mathrm{E}-02$ & Actinobacteria & Microbacterium \\
\hline Otu00008 & 0.638 & 8.05E-04 & $3.52 \mathrm{E}-02$ & Firmicutes & Ruminococcus_2 \\
\hline Otu00908 & 0.635 & $8.68 \mathrm{E}-04$ & $3.62 \mathrm{E}-02$ & Proteobacteria & Legionella \\
\hline \multicolumn{6}{|c|}{ sul1 } \\
\hline OTU & cor. coeff. & p-value & adj. p-value & Phylum & Genus \\
\hline Otu00188 & 0.882 & $1.18 \mathrm{E}-08$ & $1.83 \mathrm{E}-05$ & Actinobacteria & Actinomycetaceae_unclassified \\
\hline Otu00019 & 0.856 & $9.86 \mathrm{E}-08$ & $5.66 \mathrm{E}-05$ & Actinobacteria & Leucobacter \\
\hline Otu00044 & 0.850 & $1.45 \mathrm{E}-07$ & $5.80 \mathrm{E}-05$ & Actinobacteria & Collinsella \\
\hline Otu00154 & 0.843 & 2.41E-07 & $6.70 \mathrm{E}-05$ & Actinobacteria & Ornithinibacter \\
\hline Otu00216 & 0.840 & 2.86E-07 & $7.62 \mathrm{E}-05$ & Firmicutes & Firmicutes_unclassified \\
\hline Otu00035 & 0.835 & 3.79E-07 & 8.64E-05 & Firmicutes & Trichococcus \\
\hline Otu00349 & 0.827 & $6.42 \mathrm{E}-07$ & 1.17E-04 & Proteobacteria & Devosia \\
\hline Otu00164 & 0.826 & 6.61E-07 & 1.17E-04 & Actinobacteria & Bifidobacterium \\
\hline Otu00366 & 0.821 & 8.69E-07 & $1.42 \mathrm{E}-04$ & Firmicutes & Acetobacterium \\
\hline Otu00945 & 0.816 & $1.18 \mathrm{E}-06$ & $1.76 \mathrm{E}-04$ & Saccharibacteria & Saccharibacteria_unclassified \\
\hline
\end{tabular}

2 